\section{En flora av muligheter og utfordringer}

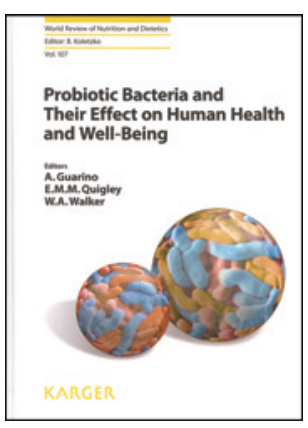

Alfredo Guarino, Eamonn M. M. Quigley, W. Allan Walker, red.

Probiotic bacteria and their effect on human health and well-being

201 s, tab, ill. Basel: Karger, 2013.

Pris CHF 196

ISBN 978-3-318-02324-4

Probiotika (latin, pro- = for; gresk, bios $=$ liv) er levende mikrober som kan gi helsefremmende effekter ved tilførsel gjennom magetarm-kanalen. Hensikten med artikkelsamlingen Probiotic bacteria and their effect on human health and well-being er ifølge redaktørene å gi en oppdatering om probiotika for leger, biologer, bioteknologer og forskere innen matindustri, jordbruk, helsevesen, miljøvitenskap og basalvitenskap.

Boken inneholder 21 relativt korte oversiktsartikler om ulike aspekter ved tarmbakterier. Redaktørene har innhentet bidrag fra toppforskere fra hele verden, inkludert «vår egen» Per Brandtzæg, som har skrevet et leseverdig kapittel om hvordan tarmens første møte med mikrober påvirker modningen av immunsystemet.

I første del berøres en rekke spennende spørsmål: Endrer tarmfloraen seg gjennom livet? Påvirker mikrobene psyken? Kan bakteriene gjøre oss fete? Påfølgende kapitler handler om bruk av probiotika ved ulike sykdommer, og i siste del fremlegger forfatterne interessante fremtidsperspektiver. Artiklene utgjør ingen pedagogisk tilrettelagt innføringsbok, men er et utvalg tekster for spesielt interesserte.

Rent utseendemessig er boken grå og trist, og det er få gode illustrasjoner. Kapittelutvalget virker litt tilfeldig: Det er for eksempel rart at inflammatorisk tarmsykdom kun omtales hos barn, mens andre tilstander omtales hos både barn og voksne. Redigeringen kunne nok vært noe strammere, men samtidig er det kanskje en fordel at forfatterne har fått spillerom til å skrive om sine favorittemaer.

Ideen om at vi kan bli friskere av å spise visse mikrober er ikke ny. Fermenterte meieriprodukter er lenge blitt oppfattet som særlig helsebringende, og det hevdes at den bibelske Abrahams høye alder skyldtes jevnlig inntak av surmelk (det er anslått at han ble 175 år gammel). Forestillingen om at bakterier kan være bra for oss ble første gang formulert av russeren Élie Metchnikoff (1845-1916) for over 100 år siden, blant annet basert på observasjoner av tatarenes store yoghurtkonsum.

Selve probiotikabegrepet er likevel av nyere dato, og inntaket av slike produkter er nå større enn noen gang. Probiotic bacteria and their effect on human health and well-being utruster oss med solid og oppdatert bakgrunnskunnskap for å møte denne utviklingen. Ikke minst tydeliggjør forfatterne hvor lite vi egentlig vet om manipulering av tarmfloraen. Det er fortjenstfullt at redaktørene har inkludert et eget kapittel om potensielle farer ved bruk av probiotika, men dette viktige aspektet kunne med fordel vært problematisert i enda større grad. Vitenskapskomiteen for mattrygghet har utgitt langt mer utførlige risikovurderinger for bruk av probiotika, og disse rapportene kan leses gratis via komiteens internettsider $-w w w . v k m . n o$. Det er lite som tyder på at det er farlig å spise probiotika for friske mennesker, men konsekvensene på lang sikt er ukjente. Veien til god helse går kanskje via magen - men probiotika er ikke uten videre det beste fremkomstmidlet.

\section{Klassiker i nyutgivelse}

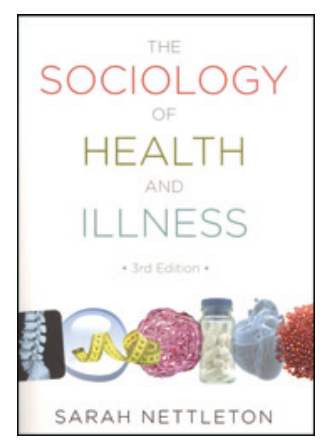

\author{
Sarah Nettleton \\ The sociology of health and illness
}

3. utg. 292 s, tab, ill. Cambridge: Polity Press,

2013. Pris GBP 20

ISBN 978-0-7456-4601-5

Helse og samfunn står i et gjensidig forhold til hverandre. Vår forståelse og håndtering av helse og sykdom er derfor $\mathrm{i}$ kontinuerlig endring, i takt med helsemessige, kulturelle, medisinskfaglige, teknologiske og organisatoriske endringer. Dette er hovedtemaet i denne tredje og omfattende reviderte utgaven av Sarah Nettletons velkjente lærebok i medisinsk sosiologi, første gang utgitt i 1995. Boken er dagsaktuell og praksisrelevant $i$ den forstand at den tar for seg hvordan samfunnsmessige endringer påvirker det meste av det som har med helse og sykdom å gjøre, inkludert implikasjoner for praksisutøvelsen. Den er relevant for både forskere, klinikere og studenter i medisinske fag.

Boken spenner over et bredt felt både tematisk og teoretisk, samtidig som den går i dybden på sentrale dagsaktuelle temaer. Fordelt på ti kapitler tar forfatteren systematisk for seg de mest grunnleggende temaene i den medisinske sosiologien. Begreper som helse, sykdom, kultur, rolle, stigma, risiko, kronisk sykdom, kropp, medikalisering, profesjon og konstruktivisme blir drøftet. Introduksjonskapitlet rammer det hele inn med en historisk orientert oversikt over medisinsksosiologiske tenkemåter, i tillegg til fagets relasjon til biomedisinen. Et hovedargument her er at grensene mellom medisin og medisinsk sosiologi blir stadig mer utydelige, og at de to fagene derfor blir mer overlappende.

I de påfølgende ni kapitlene tar forfatteren for seg mer spesifikke empiriske emner. Kapittel 2 omhandler den medisinske kunnskapens forbindelse til den historiske og kulturelle konteksten den skapes og brukes i. Kapittel 3 og 4 handler om folkelige helseforståelser, kronisk sykdom og funksjonshemning. I kapittel 5 er temaet kroppen og ulike forståelser av den. Kapittel 6 dreier seg om relasjonelle aspekter knyttet til samhandling mellom pasient og behandler. I kapittel 7 diskuteres sosiale helseulikheter. Kapittel 8 berører helseprofesjonenes rolle og status. Kapittel 9 behandler helseteknologi, og kapittel 10 helsepolitikk. Avslutningsvis følger referanseliste på 30 sider og et stikkordregister.

En bok med en bredde som dette står i fare for å bli overfladisk, men Nettleton har klart det kunststykket å sikre både bredde og dybde. Innsiktsfullt, grundig og samvittighetsfullt loser hun oss gjennom det ene temaet etter det andre, på en reflekterende og tillitvekkende måte. Både nybegynnere og de litt mer erfarne vil ha nytte av boken.

Kvaliteten styrkes av at all tekst er forfattet av samme person. Mange lærebøker i medisinsk sosiologi er artikkelsamlinger med mangel på sammenheng og konsistens. Noe av det fine her er at de ulike kapitlene refererer til hverandre og således bindes sammen på en måte som gjør teksten til en konsistent helhet. Endringer i sykdomspanoramaet i retning av kroniske lidelser er en slik rød tråd.

\section{Olaug S. Lian}

Institutt for samfunnsmedisin

Universitetet i Tromsø 